\title{
PENGARUH TREATMENT UREA TERHADAP KANDUNGAN SERAT KASAR PADA KULIT UBI KAYU UNTUK BAHAN BAKU PAKAN IKAN
}

\author{
Erlania") dan Mulyasari") \\ ") Pusat Penelitian dan Pengembangan Perikanan Budidaya \\ Jl. Ragunan 20, Pasar Minggu, Jakarta Selatan 12540 \\ E-mail: erlania_elleen@yahoo.com; erlania@cria.indosat.net.id \\ ") Balai Penelitian dan Pengembangan Budidaya Air Tawar \\ Jl. Sempur No. 1 Bogor 16154
}

\begin{abstract}
ABSTRAK
Kulit ubi kayu merupakan salah satu bahan baku alternatif yang sampai saat ini masih diteliti pemanfaatannya sebagai salah satu komponen dalam pakan ikan. Penelitian ini bertujuan untuk mengetahui penurunan serat kasar pada kulit ubi kayu yang direndam dengan larutan urea. Rancangan penelitian menggunakan rancangan acak lengkap (RAL), faktorial dengan 2 faktor perlakuan yaitu konsentrasi larutan urea $(3 \%, 5 \%$, dan $7 \%)$ dan waktu perendaman (5 hari dan 9 hari), masingmasing dengan 3 ulangan. Analisis kandungan serat kasar dilakukan sebelum (kontrol) dan setelah perendaman. Hasil penelitian menunjukkan bahwa perbedaan konsentrasi larutan urea memberikan hasil yang tidak berbeda nyata, sedangkan waktu perendaman memberikan hasil yang berbeda nyata terhadap penurunan serat kasar pada kulit ubi kayu. Waktu perendaman selama 9 hari memberikan hasil yang terbaik dengan penurunan serat kasar yang paling besar dibandingkan dengan kontrol.
\end{abstract}

\section{KATA KUNCI : serat kasar, kulit ubi kayu, bahan baku pakan, urea}

\section{PENDAHULUAN}

Permasalahan di bidang perikanan budidaya yang saat ini sudah menjadi permasalahan nasional antara lain adalah masalah pakan. Harga pakan yang melambung tinggi menyebabkan terjadinya penurunan pendapatan petani, karena harga ikan yang relatif stabil. Mahalnya harga pakan komersil disebabkan harga bahan baku yang semakin mahal dan sebagian besar merupakan produk impor. Untuk mengatasi permasalahan ini, diperlukan bahan-bahan alternatif sebagai pengganti bahan baku pakan impor yang mahal. Salah satu yang potensial di saat ini dan pemanfaatannya masih dalam tahap penelitian adalah kulit ubi kayu.

Indonesia merupakan produsen ubi kayu dengan urutan kelima terbesar di dunia. Saat ini produksi ubi kayu nasional telah diekspor ke berbagai negara seperti RRC, Uni Eropa, Taiwan, dan Korea Selatan (Anonim, 2011). Berdasarkan data produksi ubi kayu nasional tahun 2009 sebesar 21.990.381 ton dengan luas areal panen 1.205.440 ha, limbah kulit yang dihasilkan mencapai 4.938.076-7.696.633 ton yaitu sekitar 20\% - 35\% dari total produksi (BPS, 2011; Ekundayo, 1980 in Obalua, 2007). Kulit ubi kayu yang terbuang dalam jumlah besar tersebut umumnya belum termanfaatkan secara optimal. Kulit ubi kayu tergolong potensial karena merupakan limbah, ketersediaannya berlimpah, kontinu, dan tidak bersaing dengan bahan pangan manusia.

Hasil penelitian Solomon et al. (1999) menunjukkan bahwa penggunaan 35\% kulit ubi kayu dalam pakan larva ikan nila memberikan pertumbuhan yang terbaik (Specific Growth Rate/SGR 2,40\%) dibandingkan dengan perlakuan $20 \%$ dan 30\% kulit ubi kayu, serta pakan kontrol yang menggunakan tepung jagung (SGR masing-masing 1,61\%; 2,01\%; dan 1,82\%). Hasil penelitian tersebut menunjukkan bahwa kulit ubi kayu cukup potensial digunakan sebagai bahan baku pakan ikan. Dalam pemanfaatannya sebagai campuran dalam pakan ikan, kulit ubi kayu masih memiliki keterbatasan. Bahan ini memiliki kandungan serat kasar yang cukup tinggi, yaitu sekitar 10,00\%-33,40\% dalam bobot kering (Can et al., 2004; FAO, 1992), sehingga sulit dicerna oleh ikan. Karena itu, diperlukan upaya untuk menurunkan serat kasar agar dapat meningkatkan daya cerna dari kulit 
ubi kayu tersebut, sehingga pemanfaatannya sebagai bahan baku pakan ikan bisa lebih efisien. Salah satu cara yang dapat dilakukan yaitu melalui treatment kimia yang dalam penelitian ini dilakukan dengan cara perendaman dengan larutan urea.

Perendaman bahan dengan larutan urea merupakan salah satu perlakuan kimiawi yang dikenal dengan proses amoniasi. Pada proses amoniasi, amonia yang digunakan dapat berbentuk gas, larutan, ataupun amonia yang berasal dari pemecahan urea. Urea merupakan senyawa organik yang tersusun dari unsur karbon, hidrogen, oksigen, dan nitrogen dengan rumus kimia adalah $\mathrm{CON}_{2} \mathrm{H}_{4}$ atau $\left(\mathrm{NH}_{2}\right)_{2} \mathrm{CO}$. Urea berbentuk kristal, bersifat higroskopis, dan mudah larut dalam air. Penggunaan larutan urea merupakan salah satu cara untuk menghasilkan amonia yang berperan dalam merubah komposisi dinding sel tumbuhan, terutama melepaskan ikatan antara lignin dengan selulosa dan hemiselulosa. Proses hidrolisis urea berlangsung seperti reaksi berikut:

$$
\mathrm{CO}\left(\mathrm{NH}_{2}\right)_{2}+\mathrm{H}_{2} \mathrm{O} \longrightarrow \mathrm{CO}_{2}+2 \mathrm{NH}_{3}
$$

Treatment urea, saat ini merupakan salah satu metode yang sudah dikenal untuk meningkatkan kandungan protein dari bahan baku pakan kualitas rendah (Al-Shami \& Al-Sultan, 2006). Selain untuk meningkatkan kandungan protein, diharapkan perendaman dengan larutan urea juga dapat menurunkan serat kasar. Menurut Murni et al. (2008), prinsip kerja senyawa alkali (seperti amonia) adalah memutuskan sebagian ikatan antara selulosa dan hemiselulosa dengan lignin dan silika. Penggunaan urea, memiliki beberapa keuntungan, antara lain aplikasinya mudah dan sederhana, tidak berbahaya, dan harganya juga murah (Cañeque et al., 1998). Prinsip amoniasi adalah penggunaan urea sebagai sumber amonia yang bertujuan melarutkan mineral silikat, menghidrolisis ikatan lignoselulosa dan lignohemiselulosa, meningkatkan kecernaan, meningkatkan kandungan protein kasar, serta menekan pertumbuhan jamur (Setyono et al., 2009 dalam Permata et al., 2012).

Penelitian ini bertujuan untuk mengetahui pengaruh perlakukan larutan urea dan waktu perendaman terhadap penurunan serat kasar pada kulit ubi kayu. Hasil penelitian ini diharapkan dapat bermanfaat dalam memberikan data dan informasi potensi penggunaan kulit ubi kayu sebagai bahan baku potensial untuk pakan ikan.

\section{BAHAN DAN METODE}

Penelitian dilakukan pada bulan Februari 2011 di Balai Penelitian dan Pengembangan Budidaya Air Tawar (BPPBAT) Bogor. Bahan yang digunakan adalah kulit ubi kayu yang sudah dibersihkan dari kulit ari kemudian dijemur hingga kering (penjemuran hanya bertujuan untuk pengawetan kulit ubi kayu agar tidak busuk) dan urea teknis yang dilarutkan dalam air untuk mendapatkan larutan urea untuk perendaman. Larutan urea dibuat dengan melarutkan $30 \mathrm{~g}$, $50 \mathrm{~g}$, dan $70 \mathrm{~g}$ urea dalam $1.000 \mathrm{~mL}$ air untuk menghasilkan larutan dengan konsentrasi 3\%, 5\%, dan 7\%. Waktu perendaman (ureolysis periods) dilakukan selama 5 hari dan 9 hari. Wadah perendaman kulit ubi kayu adalah gelas piala yang ditutup dengan aluminium foil. Kulit ubi kayu yang telah direndam dengan urea selama 5 hari dan 9 hari kemudian dibilas dengan air bersih untuk menghilangkan sisa-sisa urea. Analisis serat kasar dilakukan sebelum dan setelah perlakuan.

Rancangan percobaan yang digunakan adalah rancangan acak lengkap (RAL) faktorial dengan dua faktor perlakuan, yaitu konsentrasi larutan urea $(3 \%, 5 \%, 7 \%)$ dan waktu perendaman (5 hari dan 9 hari), masing-masing dengan 3 ulangan. Kemudian dilakukan analisis ragam terhadap data hasil pengukuran serat kasar.

\section{HASIL DAN BAHASAN}

Perlakukan perendaman dengan larutan urea dengan tiga konsentrasi dan lama waktu perendaman yang berbeda menunjukkan terjadinya penurunan kandungan serat kasar pada kulit ubi kayu (Gambar 1). Berdasarkan hasil analisis ragam, perbedaan konsentrasi larutan urea tidak memberikan pengaruh yang berbeda nyata terhadap penurunan serat kasar; sedangkan perbedaan waktu perendaman memberikan pengaruh nyata.

Perendaman yang dilakukan selama 9 hari menunjukkan penurunan serat kasar yang lebih besar dibandingkan dengan yang direndam selama 5 hari. Dalam Cañeque et al. (1998) juga disebutkan bahwa durasi perendaman merupakan faktor kunci keberhasilan dari treatment urea. Hasil penelitian Cañeque et al. (1998) terhadap jerami yang diberi perlakuan urea 5\% menunjukkan bahwa dengan memperpanjang waktu perlakuan menyebabkan turunnya kandungan NDF (Neutral Detergent Fiber). Namun demikian, interaksi kedua faktor 


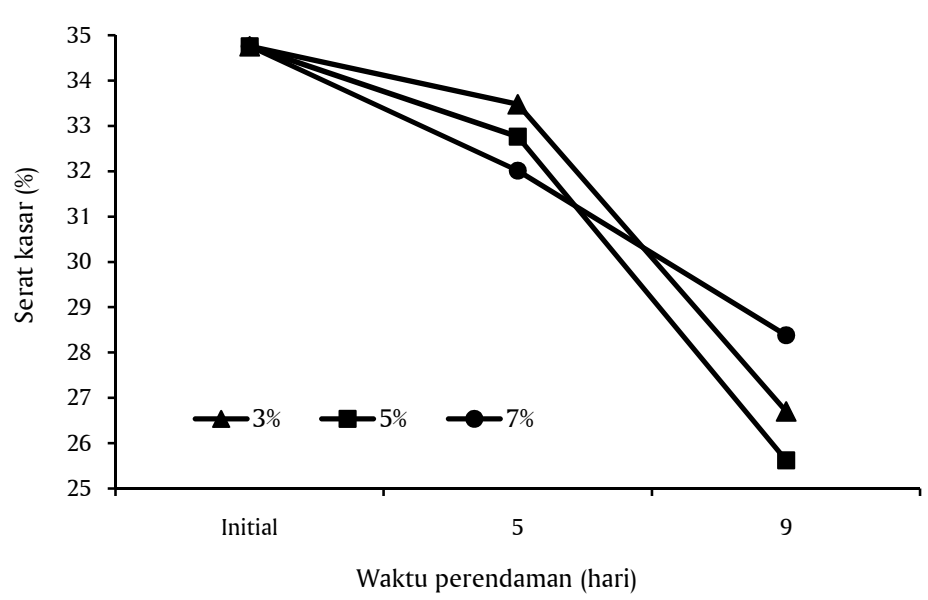

Gambar 1. Penurunan kandungan serat kasar pada kulit ubi kayu

Tabel 1. Hasil analisis proksimat kulit ubi kayu (\%, DW)

\begin{tabular}{|c|c|c|c|c|c|c|c|}
\hline \multirow{3}{*}{$\begin{array}{c}\text { Parameter } \\
\text { analisis }\end{array}$} & \multicolumn{7}{|c|}{ Perlakuan } \\
\hline & \multirow{2}{*}{ Kontrol } & \multicolumn{3}{|c|}{5 hari } & \multicolumn{3}{|c|}{9 hari } \\
\hline & & $3 \%$ & $5 \%$ & $7 \%$ & $3 \%$ & $5 \%$ & $7 \%$ \\
\hline Kadar air & 31,92 & 79,81 & 79,46 & 80,41 & 75,55 & 77,6 & 77,98 \\
\hline Protein & 8,64 & 11,215 & 10,11 & 12,2 & 10,56 & 10,74 & 10,92 \\
\hline Lemak & 1,56 & 1,45 & 0,77 & 0,77 & 0,48 & 0,75 & 1,46 \\
\hline Kadar abu & 4,09 & 2,14 & 2,66 & 2,66 & 2,75 & 2,7 & 2,97 \\
\hline
\end{tabular}

perlakukan (konsentrasi larutan dan waktu perendaman) tidak menunjukkan hasil yang berbeda nyata.

Perendaman terhadap kulit ubi kayu dengan larutan urea menyebabkan terjadinya perubahan warna dari putih kecoklatan menjadi coklat tua. Kondisi fisik kulit ubi kayu mengalami perubahan di mana sebelum direndam teksturnya cukup keras dan liat, kemudian menjadi sangat rapuh setelah dilakukan perendaman. Menurut Murni et al. (2008), hal ini dapat disebabkan karena urea sebagai senyawa alkali mempunyai kemampuan untuk mengurangi ikatan hidrogen di dalam molekul selulosa kristal, sehingga selulosa membengkak dan bagian selulosa kristal berkurang, di mana pembengkakan selulosa menyebabkan renggangnya ikatan lignoselulosa dan lignohemiselulosa, kemudian pecah, sehingga dinding sel menjadi lemah.

Seluruh sampel kulit ubi kayu yang digunakan dalam perlakuan, menghasilkan bau amonia setelah direndam. Prinsip dari treatment urea mencakup pelepasan amonia dari urea, terkait dengan pengaruh dari enzim urease (Cañeque et al., 1998). Menurut Murni et al. (2008), perlakuan urea merupakan hasil dari dua proses yang berlangsung secara simultan, yaitu hidrolisis urea (ureolysis) dan kerja amonia terhadap dinding sel bahan. Terjadinya penurunan kandungan serat kasar pada bahan pakan disebabkan karena terjadinya perubahan struktur dinding sel akibat perlakuan amoniasi, di mana terjadi proses hidrolisis dari urea yang mampu memecah ikatan lignoselulosa dan lignohemiselulosa, serta melarutkan silika dan lignin yang terdapat dalam dinding sel bahan pakan berserat (Permata et al., 2012).

Selain dilakukannya pengukuran serat kasar terhadap kulit ubi kayu yang telah di-treatment dengan larutan urea, juga dilakukan analisis terhadap parameter nutrisi lainnya, yaitu protein, lemak, abu, dan kadar air (Tabel 1). Data uji proksimat menunjukkan bahwa terdapat peningkatan protein dan penurunan kandungan lemak dari kulit ubi kayu setelah perendaman. Mascarenhas-Ferreira et al. (1989) in Cañeque et al. (1998) juga mengemukakan bahwa bahan yang diberi perlakuan urea mengalami perbaikan nilai nutrisi yang signifikan seiring dengan perpanjangan waktu perlakuan dari 45 hari menjadi 60 hari. Menurut Permata et al. (2012), penambahan urea dapat meningkatkan kandungan total $\mathrm{N}$ dalam bahan pakan sehingga menyebabkan peningkatan kandungan protein kasar. Belasco (1954) menyebutkan bahwa urea mengadung $42 \%-45 \%$ nitrogen yang setara dengan protein kasar antara $262 \%-281 \%$.

\section{KESIMPULAN DAN SARAN}

Hasil penelitian menunjukkan bahwa perendaman kulit ubi kayu dengan larutan urea dapat menurunkan serat kasar berkisar antara 18,34\%-23,19\%. Waktu perendaman yang lebih lama memberikan hasil yang lebih baik, yaitu penurunan kandungan serat kasar yang lebih besar. Perbedaan konsentrasi larutan urea yang digunakan tidak menunjukkan perbedaan penurunan serat kasar yang signifikan.

Untuk penelitian lebih lanjut, sebaiknya dilakukan dengan waktu perendaman yang lebih lama agar terlihat penurunan serat kasar yang lebih signifikan, sehingga diharapkan kandungan serat kasar dari kulit ubi menjadi lebih rendah, sehingga semakin potensial untuk dimanfaatkan sebagai alternatif bahan baku pakan ikan. 


\section{DAFTAR ACUAN}

Al Shami \& Al Sultan, S.A. 2006. Effect of treating wheat straw with urea on its crude protein content. Journal of Animal and Veterinary Advances, 5(5): 440-442.

Anonim. 2011. Profil komoditi ubi kayu. http://www.bi.go. id/. Diakses tanggal 27 April 2011.

Badan Pusat Statistik (BPS). 2011. Luas panen, produktivitas, dan produksi ubi kayu menurut provinsi, 2009. http:// www.bps.go.id. Diakses tanggal 11 April 2011.

Belasco, I.J. 1954. New nitrogen feed coumpounds for ruminants - a laboratory evaluation. J. Anim. Sci., 13: 601-610.

Cañeque, V., Velasco, S., \& Sancha, J.L. 1998. Nutritional value and use of ligno-cellulosic feed treated with urea in the ruminant diet. En Exploitation of Mediterranean roughage and by-products. Options Méditerranéennes, Serie B: Etudes et recherches noํㅡ, 17: 17-32.

Can, A., Denek, N., Tufenk, S., \& Bozkurt, A. 2004. Determining effect of lime and urea on crude and digestible nutrient content of wheat straw. Journal of Animal and Veterinary Advances, 3(7): 479-482.

Food and Agricultural Organization (FAO). 1992. Cassava as livestock feed in Africa. In. Hahn, S.K., Reynolds,
L., \& Egbunike, G.N. (Eds.) Proceedings of the IITA/ ILCA/University of Ibadan Workshop, 14-18 November 1988 Ibadan, Nigeria, 133 pp.

Murni, R., Suparjo, Akmal, \& Ginting, B.L. 2008. Teknologi pemanfaatan limbah untuk pakan (buku ajar). Laboratorium Makanan Ternak, Fakultas Peternakan, Universitas Jambi.

Permata, A.T., Sasmita, K.R., \& Kusnoto. 2012. Pengaruh amoniasi dengan urea pada ampas tebu terhadap kandungan bahan kering, serat kasar dan protein kasar untuk penyediaan pakan ternak. Fakultas Kedokteran Hewan, Universitas Airlangga. Surabaya, $12 \mathrm{hlm}$.

Solomon, S.G., Lamai, S.L., \& Tiamiyu, L.O. 1999. Studies on the nutritional value of cassava (Manihot utillisima) peels as energy source in the diet of Oreochromis niloticus fry fed in indoor glass aquaria. In. $13^{\text {th }}$ Annual Conference of the Fisheries Society of Nigeria (FISON), 3-8 November 1996, New Bussa, Nigeria.

Ubalua, A.O. 2007. Cassava wastes: treatment options and value addition alternatives. African Journal of Biotechnology, 6(18): 2,065-2,073.

van Soest, P.J. 2006. Rice straw the role of silica and treatment to improve quality. Animal Feed Science and Technology, 130: 137-171. 